\title{
ANALISIS PASAR VIRTUAL EVENT DI TENGAH PANDEMI COVID-19
}

\author{
M Tanggap Sasmita
}

Program Studi Bisni Perjalanan, Politeknik Pariwisata Bali

Jl. Dharmawangsa Kampial, Nusa Dua Bali, Telp: (0361)

tanggap1511@gmail.com

\author{
Received: Februari, 2020 \\ Accepted: Maret, 2020 \\ Published: Maret. 2020
}

\begin{abstract}
Since the end of 2019 the world has been hit by the Covid-19 pandemic which has led to changes in life including the world of tourism more specifically in the MICE sector and events. MICE and Event sectors adapt to these changes, one of them is by holding virtual events. Virtual events during the pandemic developed from webinars, conferences, to performances. A virtual event is something new and needs to be analyzed in-depth, in this study virtual events are analyzed from the perspective of the market. By using survey research methods, by distributing online questionnaires to 100 people, it was found that virtual events still have the opportunity to continue to be produced in the future with the high interest of the community to participate in virtual event activities even though there are various obstacles in their implementation such as duration that is too long, monotonous, and improper broadcast time
\end{abstract}

Keywords: market analysis, virtual event, Covid-19

\begin{abstract}
Abstrak
Sejak akhir tahun 2019 dunia dilanda pandemi Covid-19 yang mengakibatkan perubahan terhadap kehidupan termasuk dunia pariwisata lebih khusus pada sector MICE dan event. Sektor MICE dan Event beradaptasi terhadap perubahan tersebut salah satunya dengan mengadakan virtual event. Virtual event semasa pandemic cukup berkembang dari webinar, conference, hingga performaces. Virtual event merupakan sesuatu hal yang baru dan perlu dianalisa mendalam, dalam penelitian ini virtual event dianalisis dari sudut pasarnya. Dengan menggunakan metode penelitian survey, dengan menyebarkan kuesioner daring pada 100 orang, ditemukan bahwa virtual event masih memiliki peluang untuk dapat terus diproduksi di masa yang akan datang dengan masih tingginya minat masyarakat untuk ikut berpartisipasi dalam kegiatan virtual event walaupun terdapat berbagai kendala dalam pelaksanaannya seperti durasi yang terlalu lama, monoton, dan waktu tayang yang tidak tepat
\end{abstract}

Kata Kunci: analisis Pasar, virtual event, Covid-19

\section{PENDAHULUAN}

Pandemi Covid-19 yang mulai ditemukan di Wuhan, Tiongkok pada akhir tahun 2019 kemudian menyebar ke

seluruh pelosok penjuru negeri termasuk Indonesia sejak Februai 2020. Hal itu menyebabkan industri pariwisata yang 
dinamis dalam pergerakan manusia dipaksa untuk berhenti. Beberapa negara melakukan lockdown, menutup akses masuk ke kota atau negaranya, dipaksa untuk berada di rumah, bekerja , belajar, dan beraktifitas di rumah masing-masing.

Menurut Nalendra (2020) industri pariwisata dianggap sebagai sector yang paling terdampak, mengingat definisi pariwisata adalah perpindahan orang dari tempat tinggal ke tempat-tempat di luar lingkungan familiar mereka tidak lebih dari satu tahun berturut-turut tidak kurang dari 24 jam untuk berbagai motivasi seperti berlibur, urusan bisnis, dan keperluan lainnya. Alasan lainnya sector ini memiliki frekuensi interkasi antar orang yang sangat tinggi, sehingga berperan besar terhadap penyebaran virus dan penyakit covid-19. Inilah hal yang mendorong UNWTO untuk bersikap bahwa sector pariwisata harus berkomitmen untuk memproritaskan dan mengutamakan masyarakat dunia dan kesehatanya terlebih dahulu.

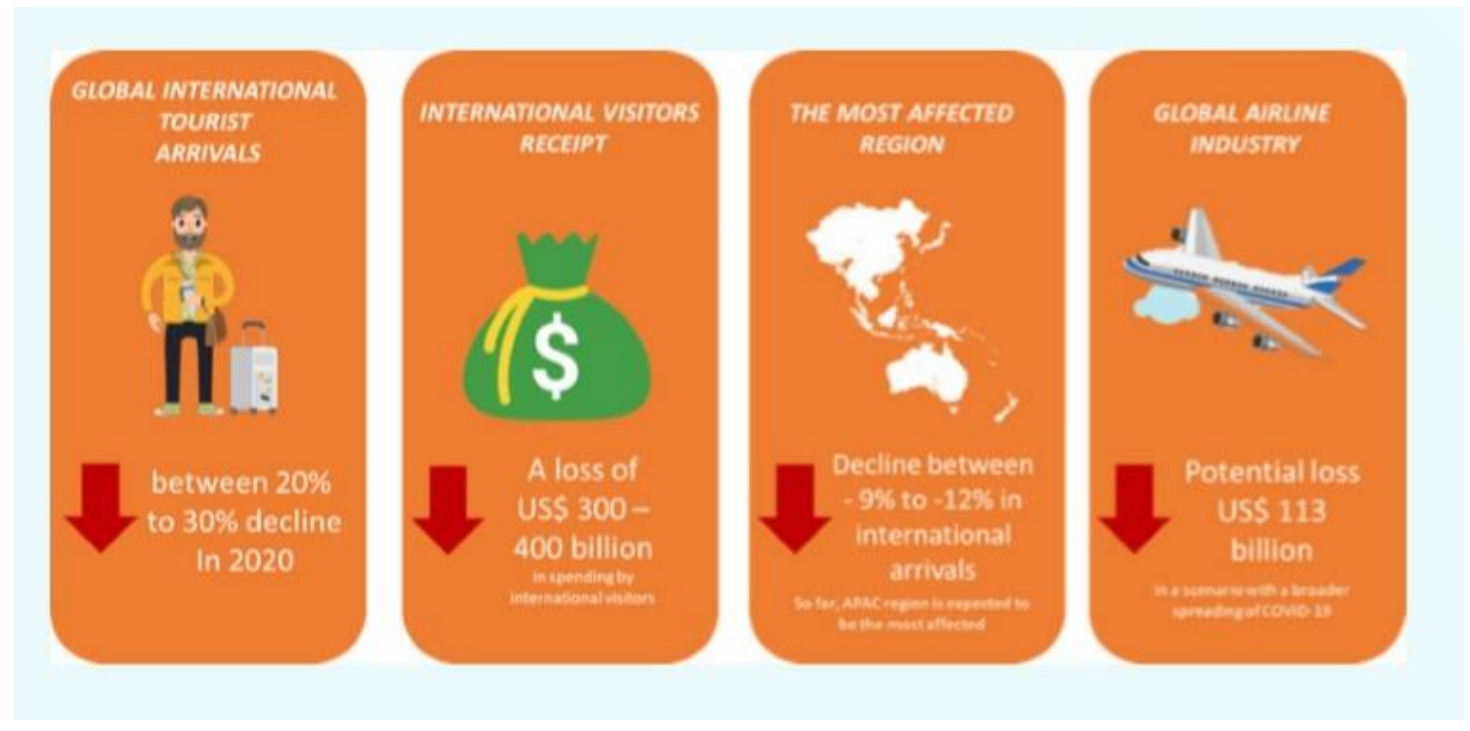

Gambar 1.Dampak Covid-19 terhadap pariwisata global

[Sumber : Nalendra, 2020]

Dari gambar di atas menunjukan Nampak bahwa kedatangan turis mancanegara turun $20-30 \%$ secara global, kemudian potensi kerugian mencapai 300-400 milliar dolar amerika. Asia pasifik merupakan region yang paling berdampak sejauh ini terdapat penuruan 9-12 \% terhadap tingkat kedatangan turis, dan industri penerbangan potensi kerugian sejauh ini mencapai 113 miliar dolar amerika.

Industri perhelatan atau event sebagai salah satu industri pariwisata juga terkena imbas yang sama, banyak event yang harus ditunda, atau bahkan dibatalkan. Tidak hanya event lokal, bahkan event nasional, dan internasional harus ditunda, seperti PON 2020 Papua dan Olimpiade Tokyo 2020 yang harus ditunda hingga tahun 2021. Berdasarkan surey yang dilakukan IVENDO Tahun 2020 terhadap 50 ribu pekerja event di Indonesia terdapat 96.43 persen kasus penundaan dan 84,86 persen kasus pembatalan event di 17 provinsi di Indonesia setelah pemerintah mengeluarkan pengumuman resmi terkait Covid-19, dari nilai tersebut potensi kerugian dari 2,69 hingga 6,94 triliun rupiah yang dibagai dalam tiga porsi besar yaitu vendor produksi, venue, dan talent. (Antara News, diakses $17 \mathrm{Mei}$ 2020)

Keadaan - keadaan serupa tersebut juga tersirat dalam beberapa artikel dari media online sebagai berikut : 

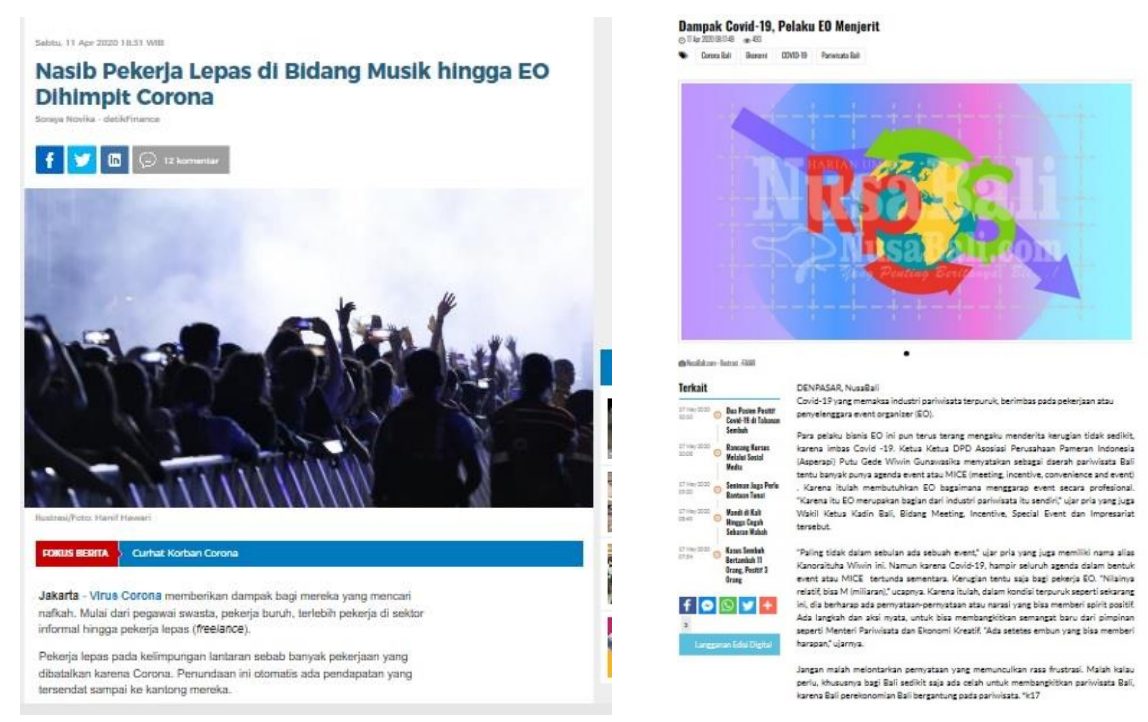

[Sumber: https://www.nusabali.com/berita/72144/dampak-covid-19-pelaku-eo-menjerit (Diakses, 17 Mei 2020)

https://finance.detik.com/berita-ekonomi-bisnis/d-4973501/nasib-pekerja-lepas-di-bidangmusik-hingga-eo-dihimpit-corona (Diakses, 17 Mei 2020)]

Menyikapi hal tersebut tersebut berbagai scenario telah dipikirkan oleh para pekerja industri event untuk dapat meminimalisasi kerugian di tengah era disrupsi akibat covid-19. Menurut Congrex Switzerland (2020) Beberapa alternative yang dapat diterapkan dalam meminimalisasi disrupsi diantaranya adalah: a) Pembatalan, hal ini dilakukan jika organizer tak mampu lagi mengelola resiko kegiatan dan mengelola vendor karena keterbatasan pergerakan untuk tetap melakasanakan kegiatan, rencana mitigasi pembatalan harus dikomunikasikan dengan baik kepada semua pihak untuk meminimalisasi semua dampak negative yang akan terjadi, b) Penundaan, dalam kasus penundaan haruslah menjadi kesepakatan banyak pihak, dan kegiatan yang berkaitan dengan informasi dan data tidak disarankan, karena jika ditunda mungkin saja informasi dan data tersebut tidak valid lagi beberapa bulan kemudiannya, c) Relokasi, memindahlan kepada lokasi yang lebih aman, dalam memindahkan lokasi semua pihak harus dikoordinasikan dan mempertimbangkan beberapa hal seperti anggaran dan perubahan informasi perubahan kepada seluruh pihak. Seiring dengan berkembangnya teknologi dan terjadinya disrupsi yang mengharuskan individu untuk lebih banyak bekerja di rumah masing-masing secara remote, terdapat alternative solusi lain yaitu; d) Hybrid Event, di mana hanya beberapa orang hadir di tempat secara fisik, sementara pengunjung atau pengunjung yang lebih besar dapat hadir menyaksikan secara online, e) Virtual Event, adalah salah satu alterenaif yang banyak dipilih dalam situasi pandemic saat ini, virtual event merupakan harapan bagi pelaku industri event untuk tetap eksis dengan tetap menerapkan prinsip pembatan sosial.

Selama bulan April 2020 bertebaran di dunia maya publikasi virtual event, mulai dari webinar, talk show, pod cast, expo, kesehatan, olahraga, pendidikan, konser musik, hingga pernikahan semua dilakukan melalui daring dengan berbagai macam platform digital mulai dari zoom, hangout, google meet, IG Live, Facebook Live, Youtube Live atau platform tersendiri. Belum ada data pasti jumlah pelaksanaan virtual event ini hingga saat ini. Berdasarkan obeservasi langsung memasuki bulan mei intensitas kegiatan ini semakin meningkat hapir setiap hari terdapat kegiatan virtual event, baik dari hanya 
puluhan viewers, ratuhan, hingga ribuan viewers dengan topik yang dibahas seputar Covid-19 ditinjau dari berbagai aspek dan prediksi.

Munculnya tren baru ini tentu menarik untuk dibahas lebih lanjut sebagai sebuah penelitian pendahualan. Dalam artikel ini akan mencoba melihat dari aspek pasar dari kegiatan virtual event ini, untuk mengikuti hambatan dan harapan peserta dari sebuah virtual event.

\section{KAJIAN PUSTAKA}

Analisis paasar adalah suatu penganalisisan atau penyelenggaran untuk memperlajari berbagai masalah pasar. Analisis pasar menyangkut lokasi pasar, luasnya pasar, sifatnya pasar dan karakteristik pasar. Analsis pasar dilakukan agar dapat memenuhi seberapa besar potensi pasar yang dapat digunkaan oleh pemasar untuk memperoleh keuntungan. Masing-masing pasar memiliki peluang masing-masing dan sangat berguna jika digunakan dengan baik.

Tujuan dari Analisa pasar adalah untuk menemuan peluang bisnis dan potensi yang bisa dimanfaatkan. Analisa pasar merupakan factor yang perlu diperhatikan oleh pemasar sebelum melakukan usaha tertentu. Hasil dari analiss tersebut berguna untuk mengetahui seberapa besar potensi bisnis yang ada dan berapa lama suatu bisnis bisa bertahan.

menurut Philip Kotler (2013) analisis pasar ialah perencanaan, pengumpulan, analisis serta pelaporan yang disusun secara sistematis berdasarkan data atau anke penemuan yang sesuai dengan situasi pemasaran tertentu. Sedangkan menurut American Marketing Association, riset pemasaran ialah fungsi yang dapat menghubungkan antara konsumen dan public dengan pemasar melalui adanya informasi dalam mengidentifikasi peluang maupun masalah pemasaran. Melalui analisis pasar akan dapat diketahui produk maupun kasa yang ditawarkan, dimana produk atau jasa itu dibutuhkan serta kualitas yang dibutuhkan dari produk atau jasa tersebut. Manfaat lain adalah agar perusahaan mengetahui besar permintaan sehingga perusahaan dapat merencankan stragei bisnisnya. Objek dari Analisa pasar adalah produk, harga, promosi, dan distribusi.

Menurut Cvent ebook (2020) Virtual event adalah pengalaman indvidu sesorang mengalami sebuah event dengan konten online dan tidak berkumpul bersama. Virtual event dapat merupakan perpaduan dari event fifik. Virtual tidak merupkan pengganti event yang lain namun merupakan tipe baru dan menambah luas dari dari jenis tipe event. Adapaun tipe dari virtual event adalah: a) Webinar, biasanya berlansung 45-80 menit, dapat menampung peserta dari seluruh belahan dunia, dapat bilaksanakan secara gratis ataupun berbayar. Webinar biasanaya menggunakan perangkat video conference dengan menyediakan fitur tanya jawab, dapat berupa siaran langsng atau direkam sebelumnya, sesuai dengan nature awalnya yang bersifat edukatif, webinar berkembang kea rah 100\% virtual. b) Virtual Conferences, sama halnya dengan conference seacara fisik, virtual conferences disusun dengan agenda yang komplkes teramsuk keynote, dibagi beberapa sesi, breakout. Dengan banyak sesi dalam virtual conferences, maka diperlukan konten dan ikatan yang kuat dengan peserta. Membangun jaringan tidak sefektif di dalam conference yang bersifat fisik, namun peserta dapat mengahadi sesi utama kemudian mengatur diri dalam ruangruang online yang disediakan untuk mengembankan jaringan, dapat menggunakan platform khusus untuk melaksanakan ini termasuk pameran yang sifatnya virtual. c) Yoga and Wellnes Sesssions, adalah pemberian sesi yoga dan atau Kesehatan secara live stream.dalam situasi pandemic sesorang akan lebih memeprhatikan kesehatanya namun dengan biaya terjangkau dan dikerjakan di rumah d) Musik dan 
Pertunjukan, sebagai Bahasa universal, musik dan pertunjukan jika disajikan secara virtual merangkum makana sesungguhnya sebagai Bahasa universal dengan jangkauan yang lebih luas. Selama pertunjukan penonton dapat memberikan komentar, kemudian meminta lagu jika diinginkan, talk shows dan podcasts, adalah sebuah event pertunjukan yang membawa isu isu terkini untuk diperbincangkan atau debat , dan dilakukan melalui portal digital.

Elemen virtual event adalah: Event Website, Event Registration, Live Presentation Content, Live, 1-way Audio/Video, Question and Answer, Live Polling, Note taking/Favorite Slides, Recorded Content, Interactive Video Conferencing, Video Surveys

\section{METODOLOGI PENELITIAN}

Dalam riset pemasaran terdapat tiga metoda yang digunakan, yaitu: a) Kuesioner, dijalankan dengan menyebarkan pertanyaan kepada calon pelanggan potensial tetnaf hal-hal terkait data yang dituhkan sesuai dengan usaha yang dijalnkan, b) Riset Grup. Metode ini dalah mebentuk kelompok-kelompok dari populasi kemudian anggota kelompok menyampaikan segala sesuatu yang dibutuhkan, mencoba produk ataupun jasa dan memberikan opini

100 responses terhadap kelebihan dan kekurangan produk atau jasa tersebutr, c) survey, metode juga dilakukan dengan memberi pertanyaan sederhana terkait dengan produk atau jasa yang ditawarkan, dilakukan secara acak dan sukarela.

Dalam penelitian metode yang digunakan adalah metode survey, kepada 100 orang responden, dengan menggunakan googleform yang disebarkan secara daring. Jenis data dalam penelitian ini adalah primer yang didapatkan dari pengumpulan kuesioner dan didukung data sekunder dari berbagai sumber, Teknik Analisa data yang digunakan dalam penelitian ini adalah deskriptif kuantitatif dengan memaknai hasil kuantitatif dari pengumpulan kuesioner.

\section{HASIL DAN PEMBAHASAN}

Berdasarkan hasil penyebaran kuesioner dapat dipaparkan sebagai berikut. Karakteristik dari responden yang diteliti dari segi usia sebagain besar berada di usia 26-30 tahun sebesar $21 \%$, kemudian 36-40 Tahun sebesar 19\%, dan 20-25 Tahun sebesar $17 \%$ sesui dengan gambar 3 di bawah, dapat diasumsikan sebagain besar dari peserta virtual event adalah kaum millennial yang dianggap mampu untuk mengakses teknologi.

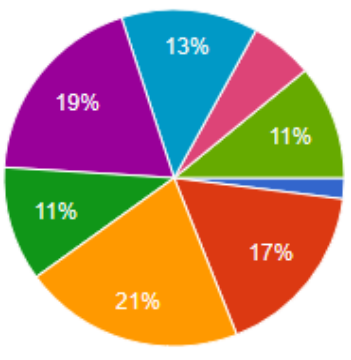

Gambar 3. Sebaran Usia Responden
Dari gambar 4 di bawah nampak bahwa keikutsertaan atau partisipasi masyarakat daam kegiatan virtual event cukup besar, sebanyak 79\% persen dari responden pernah mengikuti virtual event 
M Tanggap Sasmita

100 responses

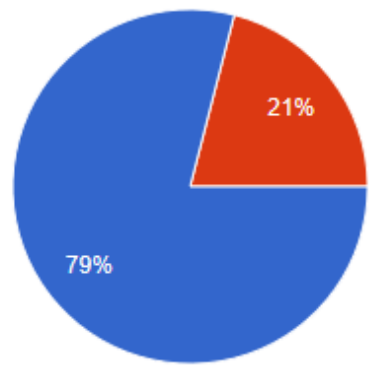

Ya

- Tidak

Gambar 4. Keikutsertaan Responden dalam Virtual Event

Dari gambar 5 nampak bahwa dari virtual event yang paling banyak pernah diikuti oleh responden adalah Webinar, kemudian diikuti oleh Virtual Conferences dan Talkshow.

100 responses

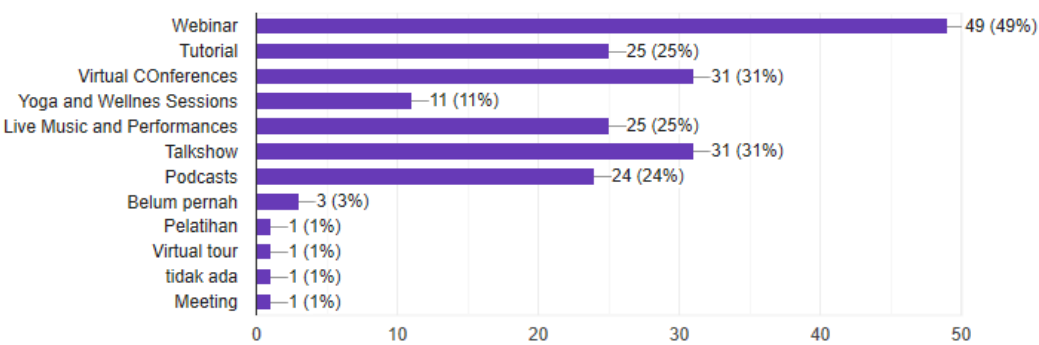

Gambar 5. Virtual Event yang pernah diikuti

Dari beberapa virtual event yang pernah diikuti oleh responden di atas, dalam gambar 6 di bawah ini menunjukkan hambatan yang didapatkan para responden dalam mengikuti virtual event, hambatan yang paling utama adalah durasi yang terlalu lama, tema yang monoton, dan waktu tayang yang tidak tepat. Hal-hal yang menjadi masalah ini merupakan hal yang perlu diperhatikan oleh pemasar untuk dicarikan solusinya.

100 responses

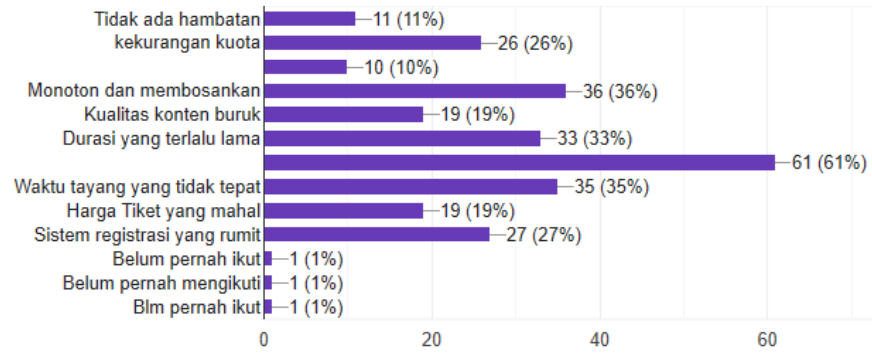

Gambar 6. Hambatan Selama Mengikuti Virtual Event

Dari gambar 7 menunjukkan bahwa masih sangat besar keinginan responden untuk mengikuti virtual event di masa yang akan datang, sebesar $72 \%$ menyatakan masih ingin mengikuti virtual event dan 29\% mungkin masih ingin mengikuti virtual event di masa yang akan datang. 

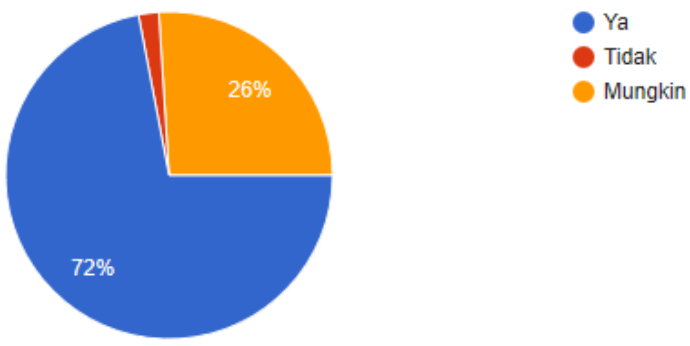

Gambar 7. Keinginan untuk mengikuti Virtual Event di Masa yang Akan Datang

Sementara dalam gambar 8 dan Performance, serta Talkshow. Bagi menunjukan jenis virtual event yang masih akan menjadi pilihan untuk diikuti di masa yang akan datang adalah Webinar, Virtual Conferences, Live Music para pemasar dapat melihat ini sebgai peluang untuk dapat menyelenggarakan kegiatan virtual di masa yang akan datang.

100 responses

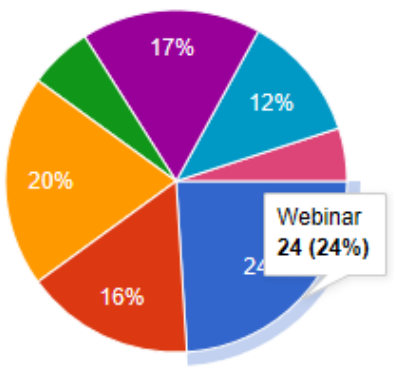

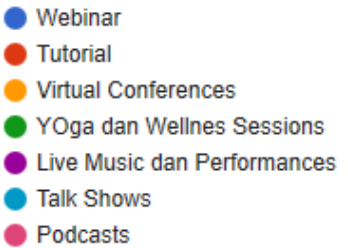

Gambar 8. Virtual Event jenis apa yang akan diikuti di masa yang akan dating

Dari virtual event yang akan diikuti di maa akan datang, dari gambar 9 dapat diketahui hal-hal apa saja yang diharapkan responden. Adapun hal-hal yang diharapkan responden paling utama adalah Konten/tema yang menarik, narasumber atau bintang tamu yang menarik, gratis, dan kualitas teknis dari virtual event tersebut seperti kualitas suara, dan kualitas gambar yang dihasilkan. Hal -hal ini perlu menjadi perhatian pemasar selanjutnya untuk mendapatkan atensi dari para peserta virtual event.

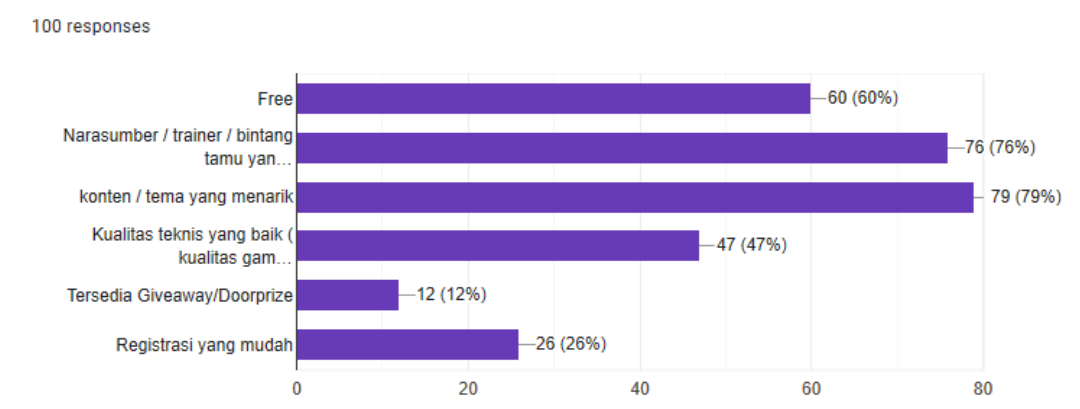

Gambar 9. Hal yang diharapkan pada Virtual Event yang akan dating 
M Tanggap Sasmita

Untuk mendapatkan informasi mengenai durasi yang nyaman dalam mengikuti virtual event, para responden memberikan jawaban bahwa durasi yang nyaman bagi mereka adalah 31-45 menit, 16-30 menit, dan atau 45-60 menit.

100 responses
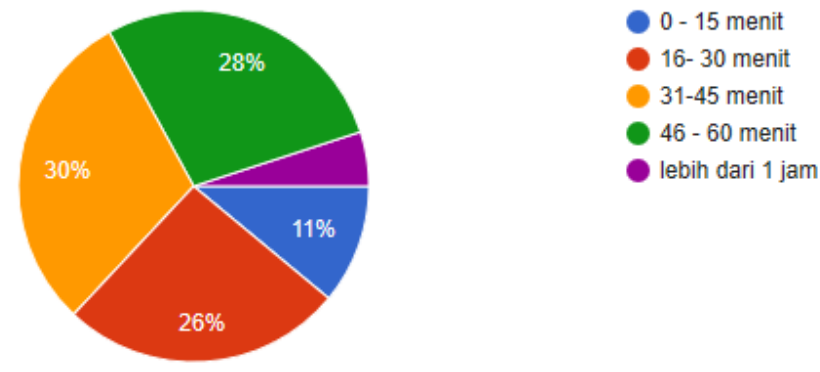

Gambar 10. Durasi yang nyaman untuk mengikuti Virtual Event

Selain durasi hal lain yang perlu diketahui adalah hari yang tepat untuk mengikuti virtual event. Setelah sebelumnya diketahui bahwa waktu yang tepat menjadi kendala dalam melaksanakan virtual event. Dari gambar
11 dan 12 di bawah diketahui bahwa hari dan waktu yang tepat adalah pada weekend dan di malam hari pada pukul 19:00 - 22:00 atau siang hari diantara pukul 11:00 - 14:00

100 responses

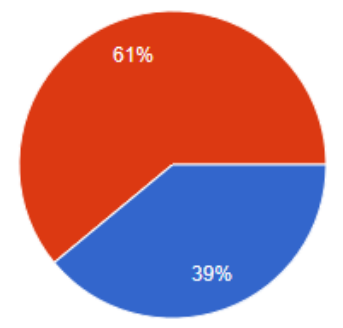

Gambar 11. Hari yang tepat untuk mengikuti Virtual Event

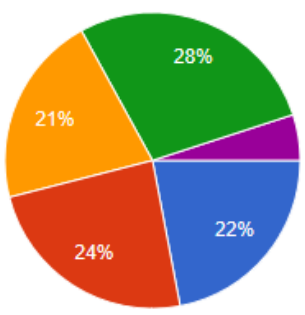

Pagi Hari ( 08:00 - 10:00)

- Diatas pukul 22:00

Gambar 12. Waktu yang tepat untuk mengikuti Virtual Event

Dari gambar 13 dapat diketahui platfrom yang dipilih oleh responden dalam mengikuti virtual event adalah zoom, IG Live ataupun Youtube Live 


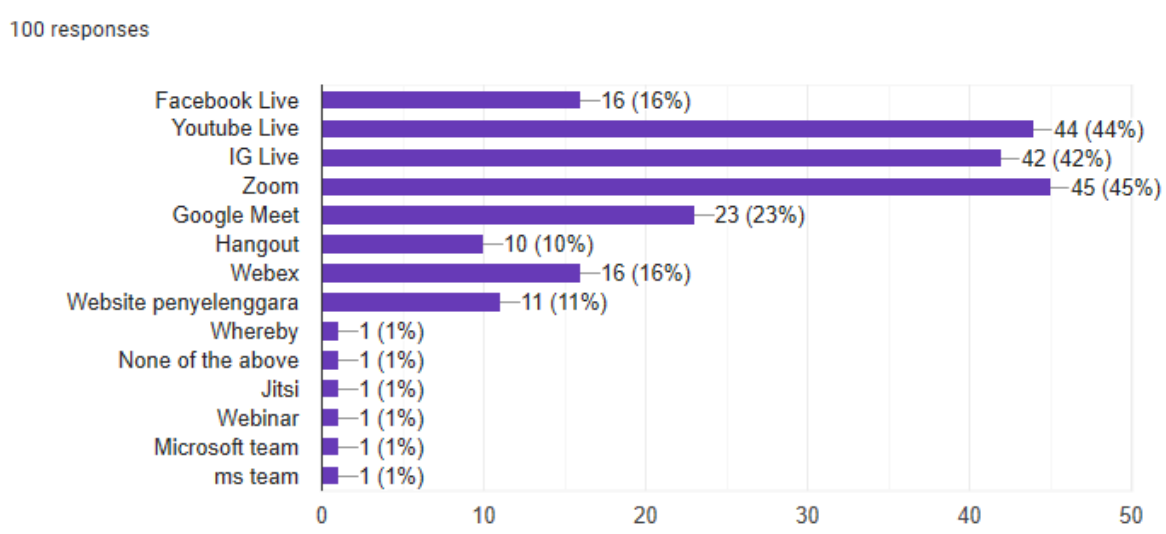

Gambar 13. Platform yang disukasi untuk mengikuti Virtual Event

Sementara secara kontinuitas secara seminggu sekali dengan jumlah Sebagian responden menginginkan responden yang memilih untuk pelaksanaan virtual event dilaksanakan dilaksanakan seminggu sekali sebanyak sebulan sekali sebanyak $43 \%$ dan atau $20 \%$.
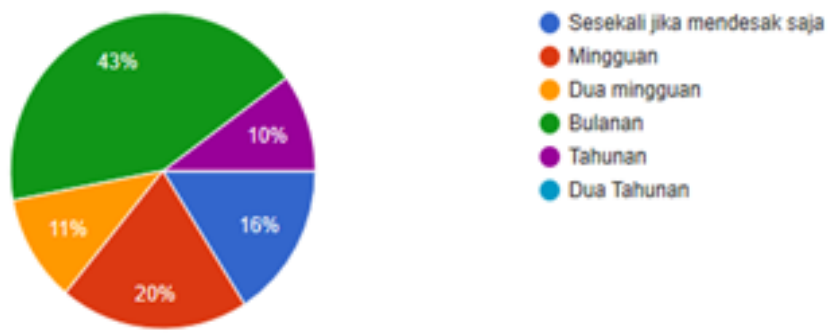

Gambar 14. Secara Kontinuitas Pelaksanaan Virtual Event

\section{KESIMPULAN}

dari pembahasan di atas dapat ditarik simpulan bahwa virtual event masih memiliki peluang untuk dapat terus diproduksi di masa yang akan datang dengan masih tingginya minat masyarakat untuk ikut berpartisipasi dalam kegiatan virtual event walaupun terdapat berbagai kendala dalam pelaksanaannya seperti durasi yang terlalu lama, monoton, dan waktu tayang yang tidak tepat. Dari kesimpulan terebut peneliti juga memberikan beberapa rekomendasi dalam pelaksanaan virtual event kedepannya untuk memperhatikan jenis virtual event yang masih diharapkan oleh masyarakat antara 30-60 menit, waktu dan durasi pelaksanaan, sebaiknya dilaksanakan pada weekend.sebaiknya pula para pelaksana memperhatikan hal- hal yang menjadi harapan masyarakat dalam pelaksanaan virtual event adalah tema yang menarik, bintang tamu yang menarik, gratis, dan kualitas teknis dari penayangany

\section{DAFTAR PUSTAKA}

nalendra, M. (2020). POST COVID-19: Travel Trends and Tourist Behavior. $4^{\text {th }}$ Markplus Tourism Weekly News Letter. Covid-19 Edition. 18 April 2020

https://bali.antaranews.com/berita/185 510/ ribuan-pekerja-industri-eventterancamkehilangan-pekerjaanakibat-covid-19. Diakses 17 Mei 2020

https://www.nusabali.com/berita/7214 4/dampak-covid-19-pelaku-eomenjerit (Diakses, 17 Mei 2020) 
M Tanggap Sasmita

https://finance.detik.com/beritaekonomibisnis/d-4973501/nasibpekerja-lepas-dibidang-musikhingga-eo-dihimpit-corona (Diakses, 17 Mei 2020)

Congrex Switzerland. 2020. Disruption in The Business Event Industry: Rising to Challenges of Covid-19. White Paper. $\quad 30 \quad$ Maret 2020 ppg.spada.ristekdikti.go.id/master/p luginfile.php/79247/mod_resource/ content/1/M O D U L \% $201 \% 20 \mathrm{~K}$ B\%201\%20KAJIAN\%20MATERI\%20 \%202\%20MENERAPKAN\%20ANALI SA\%20PASAR.pdf

Cvent, (2020). Ultimate Guide to Virtual Events.Cvent. E-book 